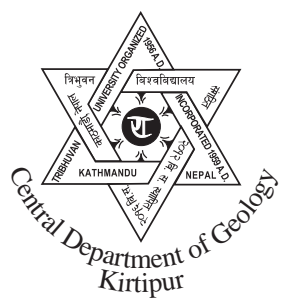

\title{
Lithologic and morphometric characteristics of the Chure River Basin, Central Nepal
}

\author{
*Naresh Kazi Tamrakar and Dharmendra Khakurel \\ Central Department of Geology, Tribhuvan University, Kathmandu, Nepal
}

\begin{abstract}
The Chure River Basin (CRB) is a small basin (width $5.75 \mathrm{~km}$, length $9.74 \mathrm{~km}$, perimeter $32.35 \mathrm{~km}$ and area $35.23 \mathrm{~km}^{2}$ ) with three sub-watersheds, and is crossed by the Tribhuvan Highway that may be threatened by riverine and allied processes. The geology and morphometry of the basin were studied to search for status of the basin development andriver dynamism. The Chure River is a sixth order river fed by rainstorm, and has length ratio of 2.79 , indicating nearly three times the average length of its fifth order segment, showing notable competency. The mean bifurcation ratio of the Chure River is 3.20, showing immature nature of the CRB. Drainage texture (DT) varies from moderate $(0.64-0.96)$ to very fine $(0-0.32)$. The Chure River is sinuous $(\mathrm{K}=1.18)$.

The relative relief (RR) is moderately low (15-30) to moderately high (120-240) and dissection index (DI) is moderate $(0.2-0.3)$ to high $(0.3-0.4)$. The CRB carries varied lithology; gravelly to coarse sandy and medium sandy and muddy, from the north to the south extension of the basin. Fine to very fine DT found in large areas because of loosely consolidated and soft lithology. Even where rocks are stiff, the presence of discontinuity has perhaps influenced the DT. Very fine to fine DT coupled with elongate nature of the basin (as indicated by low value of form factor, 0.37 ) is vulnerable to greater competency of the river during high rainfall.

RR slope and DI are found to be high in the cliff- forming lithology (stiff and well cemented), and low in other areas. High dissection, high slopes and high relief show active and immature nature of the CRB, indicating susceptibility of further incision of the Siwalik Hills and aggravation of erosion and slope movements by the immature rivers in the CRB. Presence of knick points along the river profile reflects affinity of the river to incision. The sinuosity, radius of curvature, and bifurcation ratio, all indicate immaturity of the basin. The hypsometric analysis indicates inverse relationship between the elevation and the cumulative \%area, showing active erosional condition of the basin.
\end{abstract}

Key words: Drainage texture, Relative relief, Stream order, Meander wavelength, Meander belt width

\section{INTRODUCTION}

The Chure River Basin (CRB) is located in the southern slope of the Siwalik Range (Fig. 1). The Chure and the Dudhaura Rivers are the prominent rivers of the CBR stretching between the Churia Mai Range and the Amlekhganj Bazar (Fig. 2 Geol map). This is the river basin along which country's crucial highway, Tribhuvan Highway extends. The Dudhaura Khola as a continuation of the Chure River after it confluences with the Bijaure Khola near the Bridge No. 1, immediately fans out in the Terai Plain. The Chure River has all its catchment lying in the southern

\footnotetext{
*Corresponding author:

E-mail address: ntamrakar@hotmail.com
}

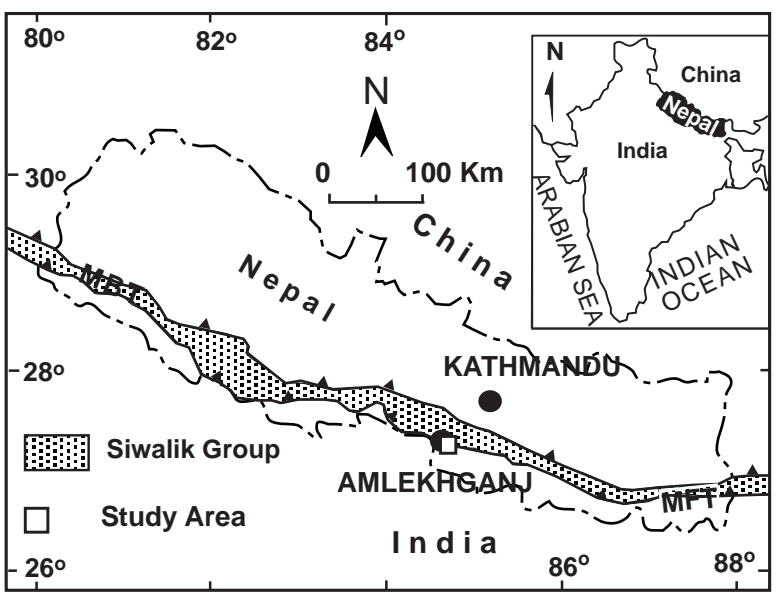

Fig. 1 A map showing Nallu Khola region, the site of sample collection: $\mathrm{MBT}=$ Main Boundary Thrust, MFT = Main Frontal Thrust 
slopes of the Churia Mai Range and the slopes formed by ridges within the basin. Because the CBR comprises various geological units of varying lithology, the erosion process and geomorphic development of landforms may partly be governed. The rivers of the CRB are active agents in carrying considerable amount of sediments and sculpturing the landforms. Several works have been conducted earlier in this locality regarding stratigraphy, sedimentology and petrography, for instance, Sah et al. (1994), Ulak and Nakayama (1998), Nakayama and ulak (1999), Tamrakar and Khakurel (2001), Tamrakar et al. (2002), Tamrakar et al. (2003), Tamrakar et al. (2007), etc. This paper documents lithology of the CRB and assesses morphometric parameters (Table 1) of the basin to trace out the nature of the basin and to compare the results of analysis with the present condition of lithology and structures. Morphometric parametrs are generally

Table 1. Definition and formulae of the morphometric parameters

\begin{tabular}{|c|c|c|c|}
\hline S.N. & |Morphometric Parameter & | Formula/Definition & Reference \\
\hline I & \multicolumn{3}{|l|}{ Linear Aspect of the Basin } \\
\hline 1 & Stream Order $(\mu)$ & Hierarchical ranking & Strahler $(1957 ; 1969)$ \\
\hline 2 & Stream Length $\left(\mathrm{L}_{\mu}\right)$ & Length of the stream & Horton (1945) \\
\hline 3 & Mean Stream Length $\left(\mathrm{L}_{\mathrm{sm}}\right)$ & $\begin{array}{c}\mathrm{Lsm}=\mathrm{L}_{\mu} / \mathrm{N}_{\mu}, \text { Where, } \mathrm{L} \mu=\text { total stream length of order } \mu \\
\mathrm{N} \mu=\text { total number of stream segment of order } \mu\end{array}$ & Strahler (1964) \\
\hline 4 & Length Ratio $\left(\mathrm{R}_{\mathrm{L}}\right)$ & $\mathrm{Rl}=\mathrm{L}_{\mu} /\left(\mathrm{L}_{\mu}-1\right)$ Where, $\mathrm{L}_{\mu}=$ cumulative mean length of the given order & Horton (1945) \\
\hline 5 & Bifurcation Ratio $\left(\mathrm{R}_{\mathrm{b}}\right)$ & $\begin{array}{c}\mathrm{Rb}=\mathrm{N}_{\mu} /\left(\mathrm{N}_{\mu}+1\right), \text { Where } \mathrm{N}_{\mu}=\text { number of streams of a given order } \\
\mathrm{N}_{\mu+1}=\text { number of stream of the next higher order }\end{array}$ & Schumn (1956) \\
\hline II & \multicolumn{3}{|l|}{ Aerial Aspects of the Basin } \\
\hline 6 & Form Factor $\left(\mathrm{R}_{\mathrm{f}}\right)$ & $\begin{array}{l}\mathrm{R}_{\mathrm{f}}=\mathrm{A} /(\mathrm{Lb})^{2}, \text { Where, } \mathrm{R}_{\mathrm{f}}=\text { form factor indicating elongation } \\
\text { of the basin shape, } \\
\mathrm{A}=\text { area of the basin, } \mathrm{L}_{\mathrm{b}}{ }^{2}=\text { maximum basin length }\end{array}$ & Horton (1932) \\
\hline 7 & Drainage Texture $\left(D_{t}\right)$ & $\begin{array}{l}\mathrm{D}_{\mathrm{t}}=1 /(\mathrm{T}+\mathrm{P}) / 2, \text { Where, } \mathrm{D}_{\mathrm{t}}=\text { drainage texture } \\
\mathrm{T}=\left[(\mathrm{t} 1+\mathrm{t} 2) /(2)^{0.5}\right. \\
\mathrm{P}=(\mathrm{p} 1+\mathrm{p} 2+\mathrm{p} 3+\mathrm{p} 4) / 4 \\
\text { Where } \mathrm{t} 1, \mathrm{t} 2=\text { number of intersections between the stream } \\
\text { network and grid square diagonals, and } \\
\mathrm{P} 1, \mathrm{p} 2, \mathrm{p} 3, \mathrm{p} 4=\text { number of intersections between the stream } \\
\text { network and grid square edge }\end{array}$ & $\begin{array}{l}\text { Horton (1945) } \\
\text { Singh, (1998) }\end{array}$ \\
\hline 8 & Patterns & & \\
\hline $8 \mathrm{a}$ & Sinuosity (K) & $\mathrm{K}=$ Length of the main stream/Length of the valley & $\begin{array}{l}\text { Leopold and Wolman } \\
(1957)\end{array}$ \\
\hline $8 \mathrm{~b}$ & -Meander wavelength $\left(\mathrm{L}_{\mathrm{m}}\right)$ & $\begin{array}{l}\text { Downstream distance between two successive curvatures of } \\
\text { the meander loops }\end{array}$ & Leopold et al. (1964) \\
\hline $8 \mathrm{c}$ & -Meander belt width $\left(\mathrm{W}_{\mathrm{blt}}\right)$ & Distance across the channel between two opposite meander loops & Leopold et al. (1964) \\
\hline $8 \mathrm{~d}$ & -Radius of curvature $\left(\mathrm{R}_{\mathrm{c}}\right)$ & $\mathrm{Rc}=\left(\mathrm{C}^{2} / 8 \mathrm{M}\right)+(\mathrm{M} / 2)$ & Leopold et al. (1964) \\
\hline III & \multicolumn{3}{|l|}{ Relief Aspects of the Basin } \\
\hline 10 & Relative relief $\left(\mathrm{R}_{\mathrm{R}}\right)$ & Difference between the highest and the lowest points (height) in a unit area & Singh, (1998) \\
\hline 11 & Dissection index & $\mathrm{DI}=$ relative relief/absolute relief & Singh, (1998) \\
\hline 12 & Hypsometric analysis & & \\
\hline 13 & Average slope & $\begin{array}{l}\text { Tan } \phi=(\mathrm{N} . \mathrm{I}) / 636.6 \\
\text { Where, } \phi=\text { average slope angle } \\
\mathrm{N}=\text { number of contour lying on the graid of square kilometer } \\
\mathrm{I}=\text { contour interval }\end{array}$ & \\
\hline 14 & Profile analysis & & \\
\hline
\end{tabular}


evaluated to understand maturity of the basin, and affinity of the river basin to various geomorphological processes in changing patterns of river and topography (Horton (1332, 1945); Leopold and Wolman (1957); Strahler (1964); Leopold et al. (1964)).

\section{METHODS}

The morphometric parameters were categorized into: linear, aerial and relief aspects of the basin, and were calculated using 1:25,000 (scale) topographic maps. Definitions of these parameters are given in Table 1.

Stream order: The entire finger tip tributaries are first order. Two first order streams produce second order, two second order produces a third order and son on (Strahler, 1957; 1969). In this process, the order of the trunk stream is not changed by the addition of the tributaries of the lower order.

\section{LITHOLOGY OF THE CHURE RIVER BASIN}

The Chure basin extends from the ridge of the Churia Mai Range in the north to the alluvial fan deposit lying in the south, near the Amlekhganj Bazar. The CBR constitutes four different lithological units in addition to the Quaternary fan deposits (Fig. 2
Geological map). These are the Upper Member of the Rapti Formation (RU), the Amlekhganj Formation (Am), the Churia Khola Formation (Ck) and the Churia Mai Formation (Cm) (Table 2 Lithostratigraphic column).

\section{Upper Member of the Rapti Formation (RU)}

The Upper Member of the Rapti Formation (RU) is distributed for a width of about a kilometer just north of the Amlekhganj Bazar, and the outcrops of the RU make up an abrupt topographic break. This zone is believed to be the inferred extension of the Main Frontal Thrust (MFT), but the actual MFT may lie further south and may be covered by the alluvium of the IndoGangatic Plain. The attitudes of the beds show steep NNE or NNW dipping beds, which in the upper part get overturned (Fig.2). The RU is composed of alternating beds of sandstone, mudstone, and siltstone with some marl beds. Mudstones are thin- to thickbedded and are of yellow grey, green grey, light grey, dark grey and yellow. Their thickness ranges from 0.10 $\mathrm{m}$ to $12 \mathrm{~m}$. Some mudstone beds are calcareous. Siltstones are thin- to thick-bedded (up to $5 \mathrm{~m}$ in thickness), and yellow grey to green grey. Some coal layers of up to $0.10 \mathrm{~m}$ are also found.

Sandstones are thick- to very thick-bedded and

Table 2: Lithostratigraphic column showing geological units distributed in the Chure River Basin (Compiled from Sah et al. (1994);

Nakayama and Ulak (1999); Gutam and Rosler (1999); Tamrakar et al. (2002))

\begin{tabular}{|c|c|c|c|c|}
\hline \multicolumn{2}{|c|}{$\begin{array}{l}\text { Formation/ } \\
\text { Member } \\
\text { (Thickness) }\end{array}$} & $\begin{array}{l}\text { Age } \\
\text { (Ma) }\end{array}$ & $\begin{array}{l}\text { Generalized } \\
\text { Column }\end{array}$ & Lithology \\
\hline \multicolumn{2}{|c|}{$\begin{array}{l}\text { Churia Mai } \\
\text { Formation } \\
(>500 \mathrm{~m})\end{array}$} & 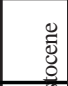 & \multirow{2}{*}{ 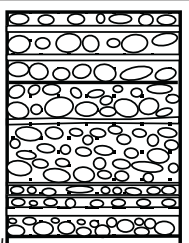 } & $\begin{array}{l}\text { Matrix-supported and poorly sorted boulder conglomerates with synsedimentary Siwalik } \\
\text { clasts, and reddish brown mudstone; the lower part is calcareous cemented with abundant } \\
\text { marble and the Siwalik sandstone clasts }\end{array}$ \\
\hline \multicolumn{2}{|c|}{$\begin{array}{l}\text { Churia } \\
\text { Khola } \\
\text { Formation } \\
(1100 \mathrm{~m})\end{array}$} & 1.8 & & $\begin{array}{l}\text { Matrix- to clast-supported,poorly sorted and loosely consolidated cobble-pebble conglomerate, } \\
\text { and minor reddish to yellowish brown mudstone and sandstone }\end{array}$ \\
\hline \multicolumn{2}{|c|}{$\begin{array}{l}\text { Amlekhganj } \\
\text { Formation } \\
(1900 \mathrm{~m})\end{array}$} & & 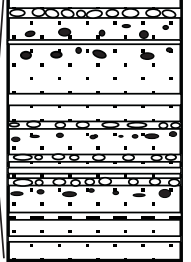 & $\begin{array}{l}\text { Cross-bedded, very coarse-grained and pebbly "salt and pepper" sandstones with sandballs } \\
\text { and mudballs, and intercalation of reddish brown to yellowish green mudstone } \\
\text { Multistoried, cross-bedded and coarse-grained "salt and pepper" sandstones with abundant } \\
\text { sandballs and mudballs, and greenish grey to yellowish grey mudstone and few pebbly } \\
\text { conglomerate layers } \\
\text { Cross-bedded and coarse-grained sandstones with abundant sandballs and mudballs, and } \\
\text { intercalation of greenish grey mudstone }\end{array}$ \\
\hline \multirow{3}{*}{$\begin{array}{l}\text { Rapti } \\
\text { Formation } \\
(>1700 \mathrm{~m})\end{array}$} & $\begin{array}{l}\text { Upper } \\
\text { Member }\end{array}$ & & 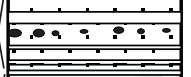 & $\begin{array}{l}\text { Cross-bedded and medium- to coarse-grained "salt and pepper" sandstones with few sandballs, } \\
\text { and greenish grey to yellowish grey mudstone and marl }\end{array}$ \\
\hline & $\begin{array}{l}\text { Middle } \\
\text { Member }\end{array}$ & & $\because \ldots$ & $\begin{array}{l}\text { Cross-laminated to massive and fine-to medium-grained sandstone, ferruginous to calcareous } \\
\text { concreted siltstone and subordinate variegated mudstone }\end{array}$ \\
\hline & $\begin{array}{l}\text { Lower } \\
\text { Member }\end{array}$ & & 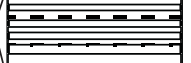 & $\begin{array}{l}\text { Cross-laminated and fine- to medium-grained sandstones, ferruginous concreted mudstone } \\
\text { and siltstone; mudstone is often variegated }\end{array}$ \\
\hline
\end{tabular}



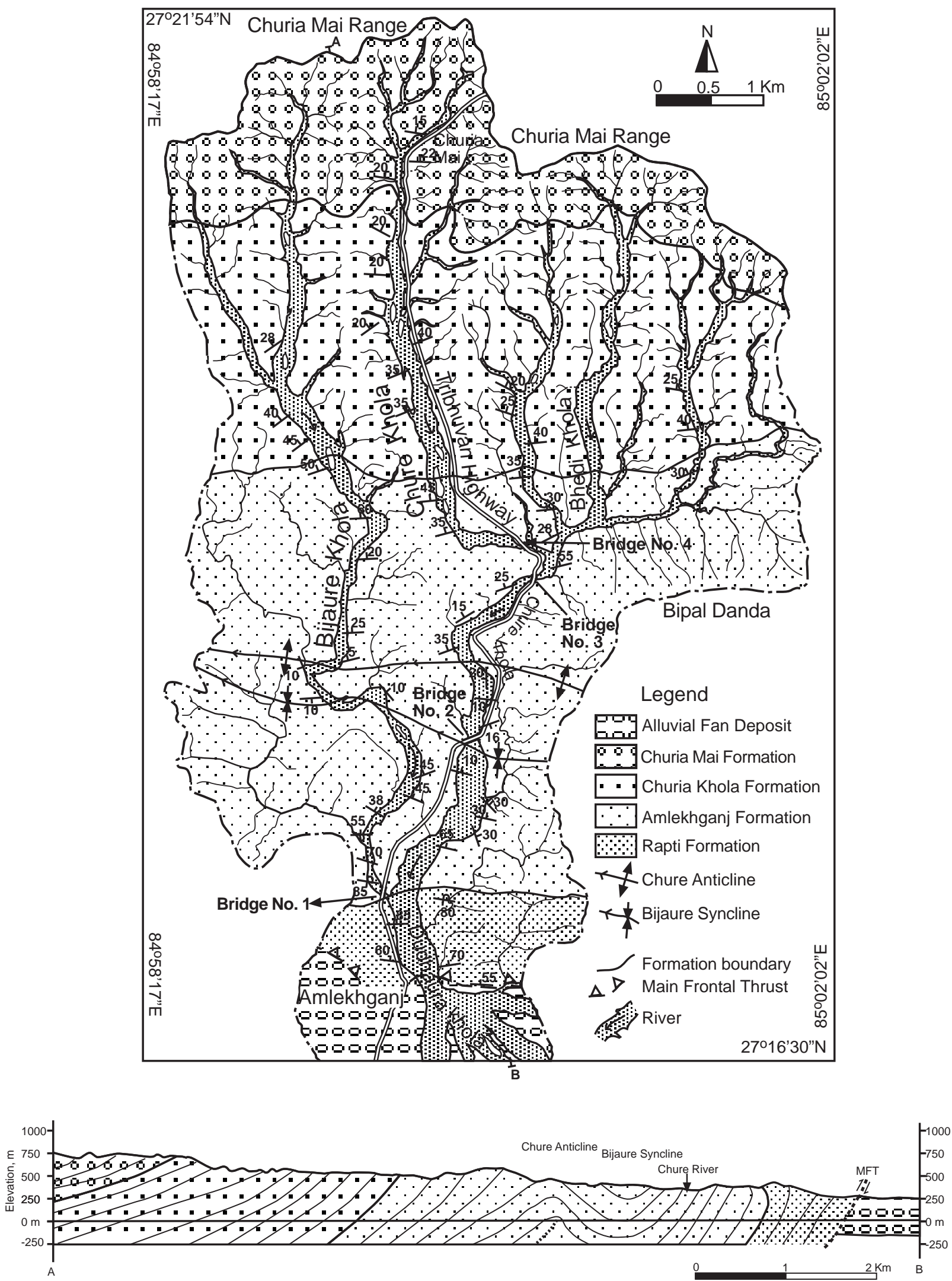

Fig. 2 Geological map and cross-section of the Chure River Basin 
their thickness varies from $0.10 \mathrm{~m}$ to $16 \mathrm{~m}$. Sandstones exhibit planar to trough cross-stratification, parallel lamination, ripple drift lamination, etc. Generally, pebbly layers occupy the lowest portion of the sandstone beds. Occasionally, some fine- to medium-grained sandstone beds are intercalated with mudstones. Clasts of muscovite, biotite, feldspars and rock fragments are distinct constituents of the rocks under unaided eye. These constituents impart 'salt-and-pepper' appearance of sandstones. The cement of sandstones is dominantly calcareous. Generally, sandstones fine upward to claystone or shale through siltstone and mudstone.

The lower part of the RU comprises thick-bedded to massive, planar to cross-bedded, medium to coarsegrained, micaceous sandstone interbedded with thinto thick-bedded, grey to green grey siltstone, shale and mudstones of light green grey, grey, yellow, maroon and yellowish green grey (Fig. 3a).

The upper part of the RU comprises thick-bedded to massive, planar to trough cross-bedded, coarsegrained to pebbly, micaceous sandstone interbedded with thick to very thick-bedded, grey to green grey, siltstone and yellow, grey and light grey green mudstones (Fig. 3b). Some marl beds (about $2 \mathrm{~m}$ thick) are also found to occur with sandstone and siltstone. The proportion of sandstone exceeds mudstone.

The total thickness of the RU in the CRB is $532 \mathrm{~m}$ and it covers $4.6 \%$ of the total area of the CRB. The distribution of the RU is limited by the inferred MFT. The Total thickness of sandstone beds, mudstone beds, siltstone beds and marl beds are $286 \mathrm{~m}, 172 \mathrm{~m}, 48 \mathrm{~m}$ and $4 \mathrm{~m}$, respectively. The remaining $30 \mathrm{~m}$ is the poor condition of exposure. The lithological assemblages and the fining upward cycles suggest for the depositional environment of the sequence to be the meandering river system.

\section{Amlekhganj Formation}

The Amlekhganj Formation is well exposed along the Chure River, and the Bijaure and Dudhara Kholas. It is characterized by multi-storied nature of 'salt-andpepper' sandstones with few beds of pebbly sandstones, mudstones and siltstones, giving rise to hogback topography. Sandstones often contain mud and sand balls throughout the formation (Tamrakar and Khakurel,
2000). Changes in reddish brown or yellow colour in place of dark grey or greenish grey of mudstone and matrix of conglomerates are noticeable. Thickness of the formation approaches to $1500 \mathrm{~m}$. The entire Amlekhganj Formation comprises several fining upward cycles with thin overall coarsening upward sequence.

Lithology of the lower part of the Amlekhganj Formation is represented by massive $(<50 \mathrm{~m}$ thick), cross-bedded, very coarse-grained, micaceous 'saltand-pepper' sandstone including some interbeddings of pebbly conglomerate and thin- to thick-bedded (up to $3 \mathrm{~m}$ ), grey mudstones (Fig. 4a). Most of the pebble layers found herein are polymictic, which are composed of subrounded pebbles of granite, gneiss, quartzite, siltstone, sandstone, slate, marble, etc., and sandy calcareous matrix containing high amount of mica and lithic fragments. Mud ball, sand balls, and lenses of sand, lenses of pebbly conglomerate of scour-fill channels, cross-bedding, and ripple laminae and prominent structures.

The middle part of the Amlekhganj Formation comprises multistoried, planar to trough cross-stratified "salt-and-pepper" sandstones (Fig. 4b) which are rarely interbedded with greenish grey mottled mudstone and few pebbly conglomerate. Sandstones frequently contain sand ball concretions and strongly cemented layers alternating with less cemented layers. The proportion and size of sand balls and mudballs increase from the lower to the middle member. The Chure anticline and Bijaure syncline, which are westward plunging folds passing through the middle portion of the formation.

The upper part often consists of planar and occasionaly trough cross-stratified, coarse- to very coarse-grained and pebbly, sandstones associated with reddish brown and yellowish green mudstones (Fig. 5a). Sandstones also frequently possess sand ball concretions and mud balls. Few matrix-supported pebbly conglomerates appear close to the contact between the Amlekhganj and the Churia Khola formations (Fig. 5b). In overall, the coarseness and degree of looseness of the lithology increase. In fact, the proportion of pebbly conglomerate increases showing nearly east-west extention and about 40 degrees NW dipping. 

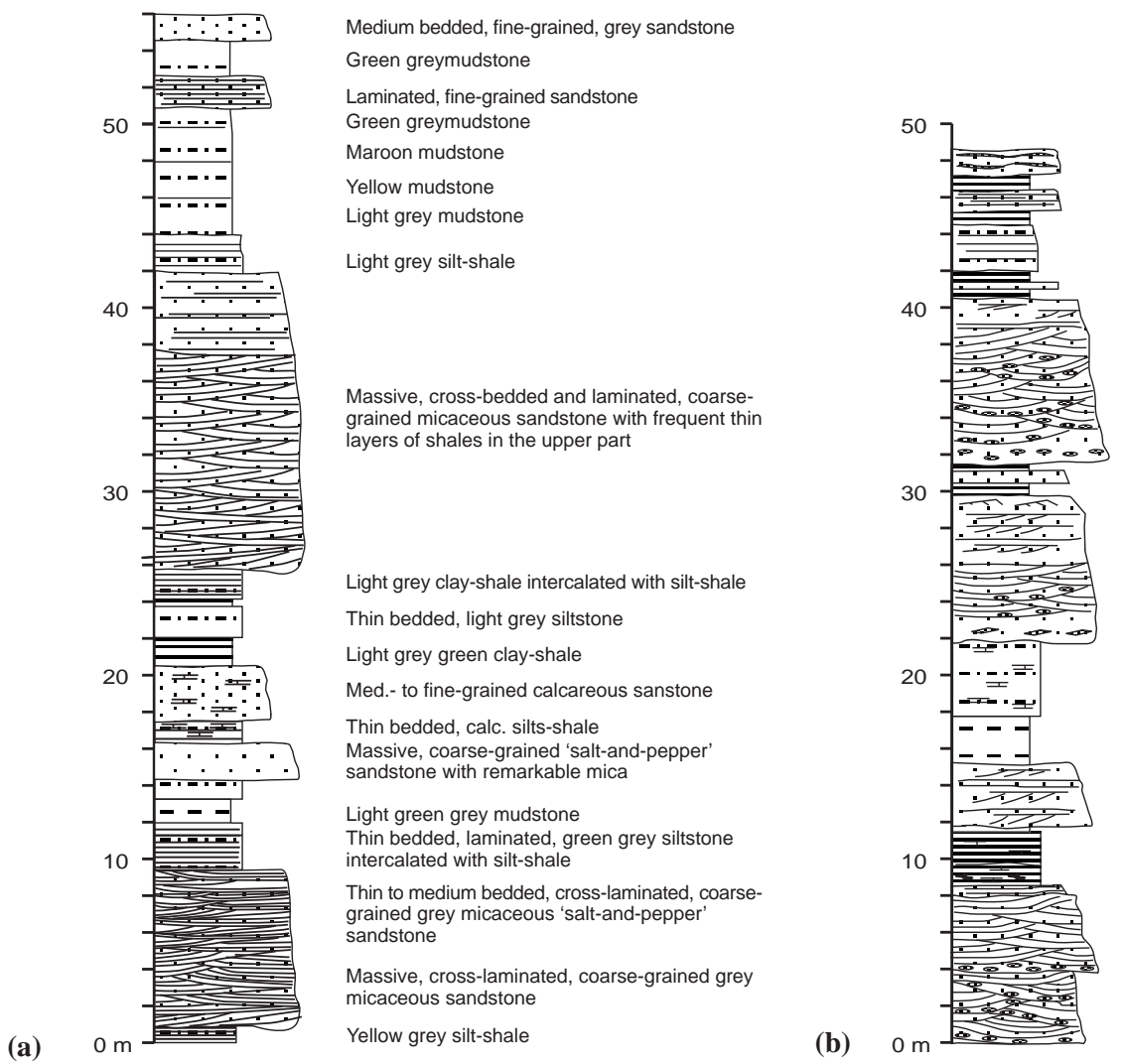

Flaser bedded, laminated, fine-grained sandstone
Light green calcareous clay-shale
V. thick-bedded, laminated siltstone
Dark grey shale
Massive, trough to planar x-bedded, very coarse-
grained 'salt and pepper' sandstone with pebbles
at the base of each set
Massive, trough to planar $x$-bedded, and ripple
laminated, coarse-grained 'salt and pepper'
sandstone with few pebbles and shale chips
Massive, yellowish green calcareous siltstone
Greenish grey mudstone

Cross-laminated, coarse-grained 'salt and pepper' sandstone

Yellowish grey calcareous concreted clay-shale

Massive, trough cross-stratified, very coarse- to coarse-grained 'salt and pepper' sandstone being pebbly at the base

Massive, trough cross-bedded, very coarse- to coarse-grained 'salt and pepper' sandstone with pebble

Fig. 3 Columnar sections of the Rapti Upper Member (RU): (a) Lower part of the RU exposed at the left bank of the Dudhaura Khola east of the Amlekhganj Bazar, and (b) Upper part of the RU at the right bank of the Dudhaura Khola near the bridge no. 1
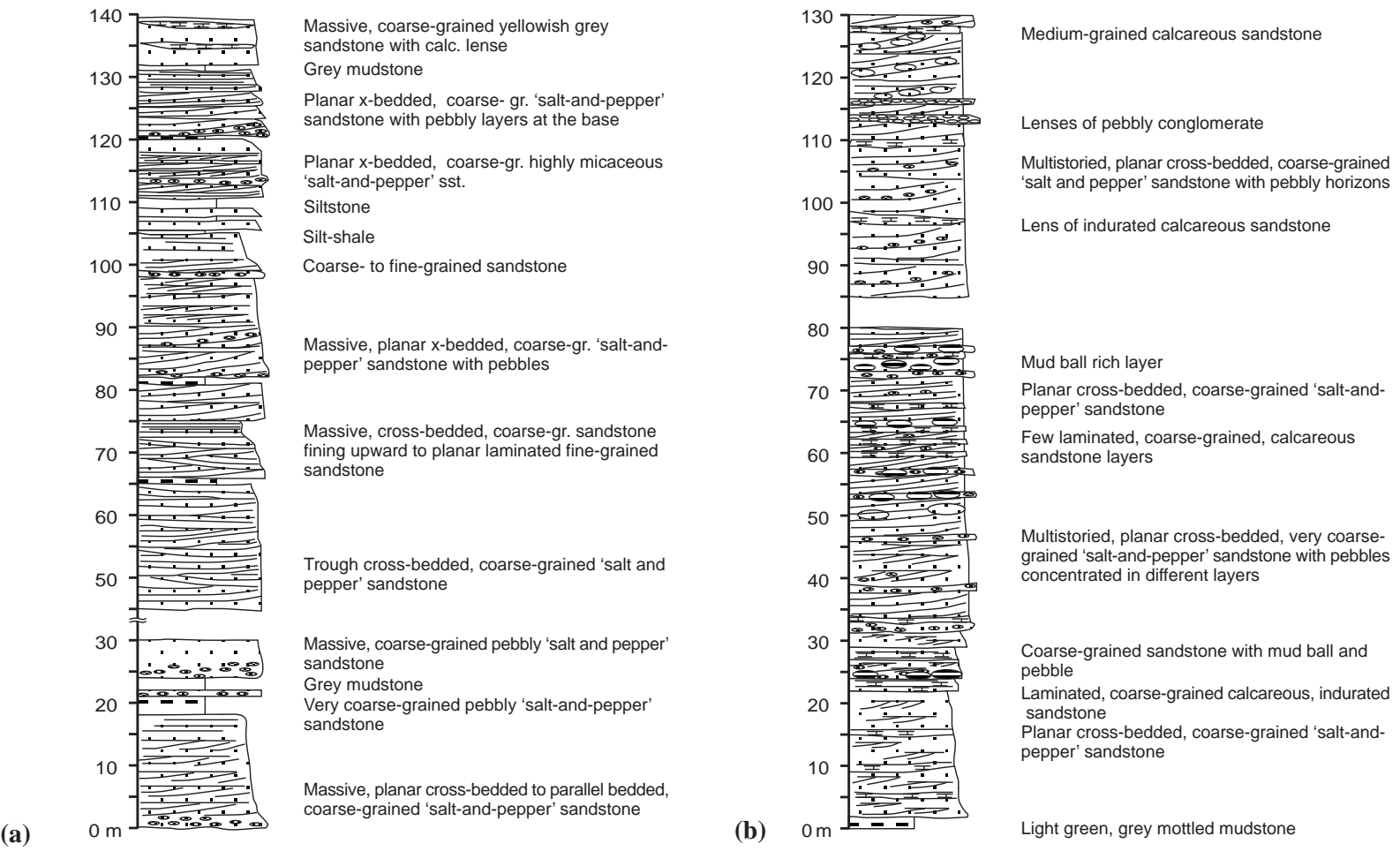

Fig. 4 Columnar sections of the Amlekhganj Formation; (a) Lower part exposed at the right bank of the Bijaure Khola, and (b) Middle part exposed at the right bank of the Chure River 
The Amlekhganj Formation covers $42.9 \%$ of the total area of the CRB. The total thickness of mudstones and siltstones is $30 \mathrm{~m}$, and that of sandstone occupies the remaining thickness. Huge thickness of the coarsegrained sandstone beds with large magnitude of thickness of cross-beds including several lenses of pebbly sandstone and conglomerate beds of channel show coarse-grained meandering river to deep sandy braided river system.

\section{Churia Khola Formation}

The Churia Khola Formation comprises clast- to matrix-supported cobble-pebble conglomerate with subordinate light brown sandstone and reddish brown to yellowish grey mudstone. It is widely distributed along the Chure River, and the Bijaure and the Bhedi Khola areas. The formation is distinguished from the hogback topography of the Amlekhganj Formation by the low-angle dipping beds (20-35 degress) characterized by irregular bad land topographic feature with several vertical fractures. The total thickness of the deposit is about $1100 \mathrm{~m}$.

At the lower part of the formation, it comprises massive, planar cross-bedded, pebbly, sandy, matrixsupported conglomerates interbedded with few layers of light yellow, bluish grey to light grey, reddish brown mudstone beds (Fig. 6a). Clasts in conglomerates are mainly composed of quartzite $(45 \%)$ granite $(30 \%)$, gneiss $(7 \%)$, sandstone and siltstone $(30 \%)$, slate $(5 \%)$ and others (5\%). Matrix is dominantly of feldspar to sand released from disintegration of granitic fragments, and constitutes $30-35 \%$.

At the middle part of the formation, it comprises graded, poorly sorted, clast dominated, pebble-cobble conglomerates (Fig. 6b). Clasts are mainly composed of gneiss, granite, slate and quartzite, and measure from 20 to $100 \mathrm{~mm}$. However, some layers with boulders of up to $0.3 \mathrm{~m}$ are found. Matrix is light yellow, and is sandy mud. It is slightly calcareous with few lenses of sandy layers. Matrix proportion is about $30 \%$. The clast size increases vertically upward.

At the upper part of the formation, conglomerates are poorly sorted, moderately clast-supported, pebblecobble to boulder-cobble. Clasts range from granule to boulder and are mostly of quartzite, gneiss, granite, marble, sandstone and siltstone. The size of the boulder is up to $350 \mathrm{~mm}$, whereas that of the cobbles and pebbles is 100 to $120 \mathrm{~mm}$ and 40 to $50 \mathrm{~mm}$, respectively. The matrix is light yellow to reddish brown and is notably calcareous. The conglomerate beds show planar cross-bedding to massive bedding, and roughly fining up of boulder dominant layers to cobble-pebble dominant layers. These sequences are interpreted to be formed in gravelly braided river system.

\section{Churia Mai Formation}

The Churia Mai Formation is distributed around the Churia Mai Range, the catchments of the Chure River, Bhedi Khola and the Bijaure Khola (Fig. 2 Geol map), and is characterized by massive, poorly sorted, matrix-supported, and boulder-cobble conglomerate showing randomly oriented clastic fabric (Fig. 7). Some pebble conglomerates are interbedded with minor sandstone and mudstone. Conglomerates frequently comprise clasts of the Siwalik rocks, e.g., 'salt-andpepper' sandstones. The formation is about $500 \mathrm{~m}$ thick, and covers about $4.6 \%$ area of the CRB.

The lower part of the formation comprises highly calcareous and stiff, poorly graded and poorly sorted boulder cobble pebble conglomerates. The latter are very much calcareous due to abundant marble and calcareous sandstone boulders and sandy matrix cemented by carbonates. Clasts of quartzite, shale, gneiss and siltstone are also found. Few beds of grey mudstone are interbedded with conglomerates.

The upper part of the formation comprises very gentle beds of matrix-supported and poorly sorted conglomerates interbedded with up to $5 \mathrm{~m}$ thick grey to yellow mudstones. Clasts of conglomerate are quartzite, granite, marble, and sandstone and siltstone of the Lower Siwaliks. They are subrounded to sub angular. Matrix of sand is yellowish brown, and becomes more abundant compared to the conglomerate of the lower part.

The vertical sequence of the Churia Mai Formation shows dominantly matrix-supported cobble to boulder conglomerate with disordered fabric, thus suggesting depositional environment of the alluvial fan system. 
Fig. 5 Columnar sections of the upper part of the

\section{Amlekhganj}

Formation; (a) From the right bank of the Chure River and (b) From the left bank of the Chure River at a contact between the Amlekhganj Formation and the Churia Khola Formation

Fig. 6 Columnar sections of the Churia Khola Formation; (a) Lower part exposed at the left bank of the Chure Khola NW from the Bridge No. 4, and (b) Upper part transitioned to the Churia Mai

Formation, exposed at the left bank of the Chure River southwest from the Churia Mai Temple

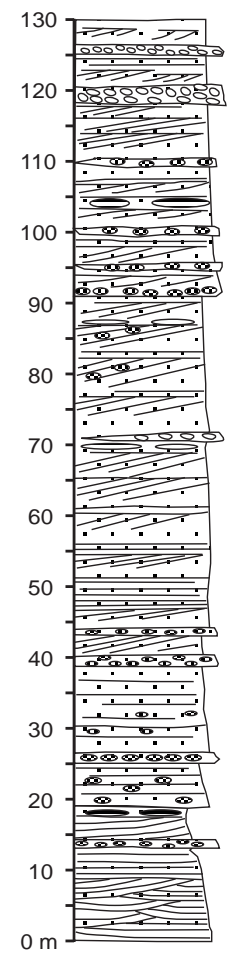

(a)
Matrix-supported, pebbly conglomerate with sandy matrix

Planar $\mathrm{x}$-bedded, very coarse-gr. sandstone with few pebbly layers and clay draps

Planar cross-bedded, coarse-grained sandstone with frequent clay draps and pebbly layers

Laminated, coarse-grained, light grey 'salt and pepper' Sst.

Planar $\mathrm{x}$-bedded, very coarse- to coarse-grained 'salt and pepper' sandstone with pebbly layers

Parallel bedded, coarse-grained light grey sandstone with few pebbles

Massive, very coarse-grained light grey sandstone with dispersed

pebbles
Very coarse-grained pebbly Ss.

Horizontal bedded, coarse-grained light grey 'salt and pepper' sandstone Trough $\mathrm{x}$-bedded, coarse-grained light grey sandstone

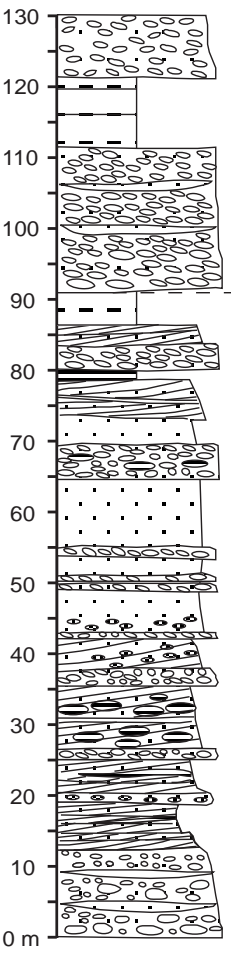

(b)

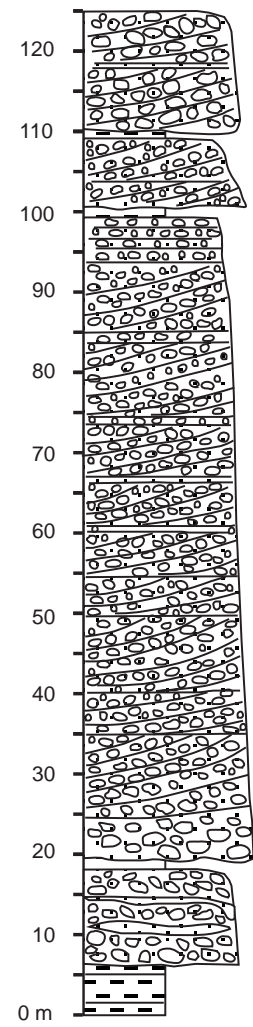

(a)
Plannar cross-bedded, cobblepebble sandy matrix-supported conglomerate; Clasts o granite,gneiss, quartizte, siltstone, Yellow mudstone

Reddish brown mudstone

Massive, Plannar cross-bedded pebbly sandy, matrix-supported conglomerate

Laminated yellow mudstone Pebbly matrix-supported conglomerate with few sandy layers

Yellow mudstone with reddish brown laminae; middle portion is bluish grey to ligh grey laminated mudstone

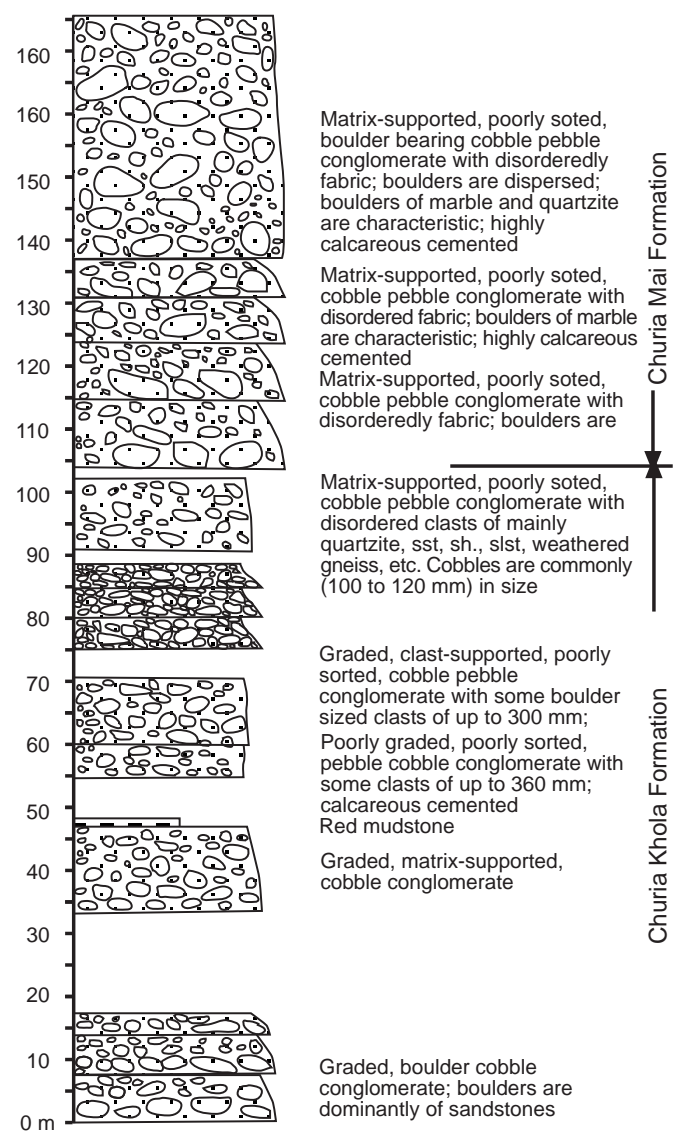

(b) Matrix-supported, poorly soted, cobble pebble conglomerate with are characteristic: highly calcareous

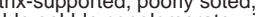
coble conglomerate quartzite, sst, sh., slst, weathered gneiss, etc. Cobbles are common

Graded, clast-supported, poorly (1) raded, poorly sorted, Poble cobble conglomerate with cemented

Graded, matrix-supported, cobble conglomerate
Matrix-supported pebbly conglomerate

Yellow mudstone

Dark to yellowish grey, lam. mudstone Yellow mudstone with reddish brown laminae

Matrix-supported, cobble-pebble Conglomerate with few sand lenses

Boundary between Amlekhganj Fm. and Churia Khola Fm.

Yellow to brown and greenish grey mudstone

Laminated yellowish grey clay-shale

Pebbly sandy conglomerate with some mud balls

Massive, coarse- to medium-grained yellowish grey sandstone

Cobble-pebble Conglomerate

Massive, pebbly, coarse-grained 'salt and pepper' sandstone

Very thick-bedded, coarse-grained 'salt and pepper' sandstone with mud balls

Planar cross-bedded, fine-grained sandstone with mud drape

Cobble-pebble Conglomerate with coarse- to fine sandy matrix (40\%); clasts are claystone, gneiss, quartzite, chert, slate, calcareous slate, etc. 


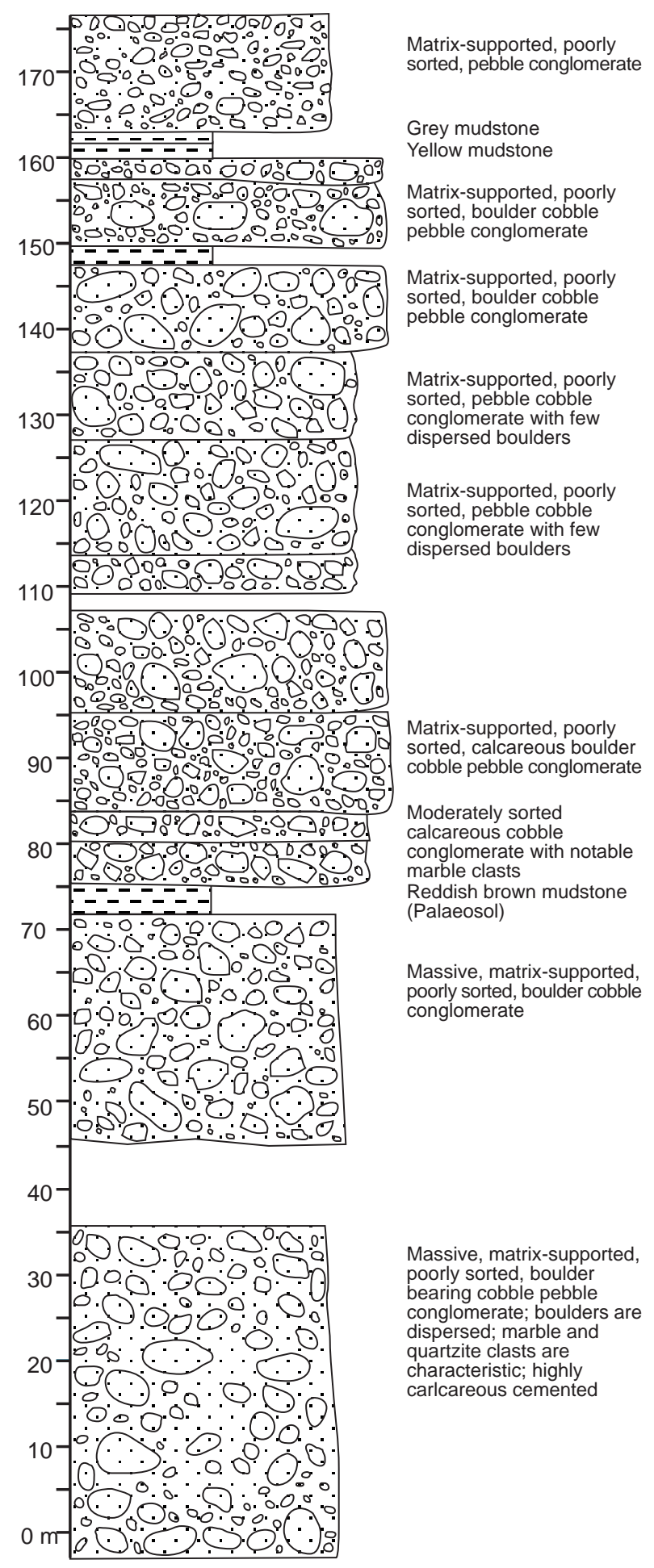

Fig. 7 Columnar section of the Churia Mai Formation; exposed at the right bank of the Chure River southwest from the Churia Mai Temple

\section{Alluvial Fan Deposit}

The Alluvial Fan Deposit comprising abundant gravel (boulder and block to pebble) mixed with sand is a recent deposit that occupies extensively the fans of the Dudhaura Khola south of Amlekhgan Bazar. Sediment of the deposit was derived locally from the southern slopes of the Churia Mai Range by the active southward flowing river systems and slope movements. Therefore, the sediment is composed of recycled gravel and sand from sandstone and conglomerate beds as well as first cycle sediments from the Siwalik Group.

\section{Recent Alluvial and Terrace Deposits}

The Recent Alluvial and Terrace Deposits comprise the recent alluvium along the river and some terrace deposits distributed at 10-15 m elevation from the current riverbeds. Some lower terrace deposits, which distribute at the sides of the Chure River, Bijaure River and the Dudhaura Khola, overlie unconformably the rocks of the Siwalik Group. These terrace deposits are composed of matrix-supported cobble boulder gravels comprising the clasts derived from the Siwalik strata located south of the Churia Mai Range.

\section{MORPHOMETRIC CHARACTERISTICS}

\section{Linear Aspects of the Chure River Basin}

Results of morphometric analyses of the linear aspect of the basin are tabulated (Table 3).

\section{Stream order}

The CBR constitutes three sub-basins, i.e., the subbasin of main stem Chure River, Bhedi Khola subbasin and the Bijaure Khola sub-basin (Fig. 8). The most of the major tributaries originating from the Churia Mai Range are flowing from the north to the south. The result of stream order analysis shows that the Bijaure Khola is the fourth order stream having average length of the channel of $6.63 \mathrm{~km}$. The Bhedi Khola is the fifth order stream which contributes the Chure River at the Bride No. 3 and enhances the order of the Chure River. From this point downstream the Chure River becomes the sixth order river. The average length of the Bhedi Khola is $0.63 \mathrm{~km}$. The sixth order Chure River has the average length of $5.25 \mathrm{~km}$. 


\section{Stream length ratio}

Stream length is the ratio of the mean length of the stream segments of a given order to mean length of the stream segments of the lower order (Table 1). It indicates a proportion of the average length of the higher order stream to the average length of the lower order stream. The larger this ratio, the greater the competence of the river to erode bank is. The forth order Bijaure Khola segment has stream length ratio of 3.45 indicating the efficient river. The Bhedi Khola has comparatively lower stream length ratio of 0.35 compared to the fifth order Chure River. The sixth order Chure River has however this ratio of 2.79, indicating nearly three times the average length of its fifth order segment.

\section{Bifurcation ratio}

Bifurcation ratio is the ratio of the stream numbers of a given order to the stream numbers of the next higher order (Table 1). The high value of bifurcation ratio reflects the immature nature of the basin that means the basin is subject to erosion and dissection by stream networks.

The ratios are quite higher in case of the first, second and third order streams of Bijaure Khola compared to other two rivers. The mean bifurcation ratios of the Bijaure Khola, Bhedi Khola and the Chure
River are 4.43, 3.16 and 3.20 respectively. The bifurcation ratio the first order streams exceeding 4 times indicates greater possibility of erosion of the catchment, presumably by gullying as the gully erosion is effective in the Siwaliks (Ghimire et al., 2006).

\section{Aerial aspects of the Chure River basin}

In the aerial aspects of the basin, parameters are calculated with respect to the area, or the parameters calculated represent aerial measurements. The Chure Khola Basin is elongated towards N-S direction Length of the basin is $9.74 \mathrm{~km}$ and its perimeter is $32.25 \mathrm{~km}$. Basin width is $5.75 \mathrm{~km}$. Basin length of the Bijaure Khola sub-basin and the Bhedi Khola sub-basin are $7.37 \mathrm{~km}$ and $4.75 \mathrm{~km}$, respectively. The area covered by the Bijaure Khola and the Bhedi Khola are 12.3 $\mathrm{km}^{2}$ and 8.37 square $\mathrm{km}^{2}$, respectively. The total area of the CRB is $35.23 \mathrm{~km}^{2}$.

\section{Form Factor}

Horton's (1932) Form Factor is a ratio that indicates the elongation of the basin shape. The lower the form factor value, the more elongated the valley is. Form factor of the CRB is 0.37. Form factors of the Bijaure Khola sub-basin and the Bhedi Khola sub-basin are 0.23 and 0.33 , respectively. These entire basins show slightly elongated nature.

Table 3: Morphometric parameters of the Chure River Basin related to drainage order, average length of channel, length ratio and bifurcation ratio

\begin{tabular}{|c|c|c|c|c|c|c|c|}
\hline $\begin{array}{l}\text { Sub- } \\
\text { basin/Basin }\end{array}$ & $\begin{array}{c}\text { Drainage } \\
\text { order }\end{array}$ & $\begin{array}{l}\text { No. of } \\
\text { streams }\end{array}$ & $\begin{array}{c}\text { Total length } \\
\text { of channel } \\
(\mathrm{km})\end{array}$ & $\begin{array}{c}\text { Average } \\
\text { length of } \\
\text { channel }(\mathrm{km})\end{array}$ & $\begin{array}{c}\text { Stream } \\
\text { length } \\
\text { ratio }\end{array}$ & $\begin{array}{l}\text { Bifurcation } \\
\quad \text { ratio }\end{array}$ & $\begin{array}{c}\text { Mean } \\
\text { Bifurcation } \\
\text { ratio }\end{array}$ \\
\hline \multirow{4}{*}{ Bijaure Khola } & 1 & 77 & 27.90 & 0.36 & - & 4.3 & \multirow{4}{*}{4.43} \\
\hline & 2 & 18 & 10.10 & 0.56 & 1.56 & 6 & \\
\hline & 3 & 3 & 5.75 & 1.92 & 3.43 & 3 & \\
\hline & 4 & 1 & 6.63 & 6.63 & 3.45 & - & \\
\hline \multirow{5}{*}{ Bhedi Khola } & 1 & 82 & 25.53 & 0.31 & - & 4.32 & \multirow{5}{*}{3.16} \\
\hline & 2 & 19 & 8.20 & 0.43 & 1.39 & 3.8 & \\
\hline & 3 & 5 & 4.30 & 0.86 & 2 & 2.5 & \\
\hline & 4 & 2 & 3.58 & 1.79 & 2.08 & 2 & \\
\hline & 5 & 1 & 0.63 & 0.63 & 0.35 & - & \\
\hline \multirow{6}{*}{$\begin{array}{l}\text { Total Basin } \\
\text { (Chure River) }\end{array}$} & 1 & 270 & 84.96 & 0.31 & - & 4.15 & \multirow{6}{*}{3.20} \\
\hline & 2 & 65 & 30.18 & 0.46 & 1.48 & 4.33 & \\
\hline & 3 & 15 & 13.95 & 0.93 & 2.02 & 2.5 & \\
\hline & 4 & 6 & 13.71 & 2.29 & 2.46 & 3 & \\
\hline & 5 & 2 & 3.76 & 1.88 & 0.82 & 2 & \\
\hline & 6 & 1 & 5.25 & 5.25 & 2.79 & - & \\
\hline
\end{tabular}




\section{Drainage texture}

The drainage texture (DT) is defined as the number of stream segment passes across per unit length within the square grid area (Horton, 1945). According to drainage texture, basin can be classified into six categories (Singh, 1998): extremely coarse (DT > $1.60)$, very coarse $(\mathrm{DT}=1.28-1.60)$, coarse $(\mathrm{DT}=$ $0.96-1.28$ ), moderate (DT $=0.64-0.96)$, fine $(\mathrm{DT}=$ $0.32-0.64)$ and very fine (DT $=0-0.32)$. Spatial distribution of drainage texture has been represented in Fig. 9 (Map showing DT). The CRB constitutes very fine to coarse drainage textures. The Amlekhganj area shows coarse drainage texture. The regions north of the Amlekhganj show gradual change from the moderate to very fine drainage texture.

Very fine DT is distributed in the catchments with south flanking slopes of the Bhedi Khola sub-basin and the main stem Chure River basins. These slopes are composed of loosely consolidated conglomerates of the Chure Khola and the Churia Mai Formations.

\section{Pattern}

The river system of the CRB exhibits commonly sub-dendritic to sub-parallel, while rectangular pattern also exists. Sinuosity $(\mathrm{K})$ that is the ratio of the length of the main stream channel to the length of the valley, of the Chure River is 1.18 showing sinuous nature according to classification of Leopold and Wolman (1957). The meander wavelength $\left(\mathrm{L}_{\mathrm{m}}\right)$, which is the distance between two successive crests of the curved channel, approaches $1034 \mathrm{~m}$. Meander belt width $\left(\mathrm{W}_{\mathrm{blt}}\right)$, which is the distance between the two lines defining the meander belt of the channel, is $332 \mathrm{~m}$ for the Chure River. Radius of curvature $\left(R_{c}\right)$ of the main stem Chure River is $541 \mathrm{~m}$. High values of $R_{c}$ and $L_{m}$ indicate that the river is not of a meandering type.

\section{Relief aspect of the basin}

The relief aspects of the basin considered are elevation of the surface, slope of the surface, relative relief, dissection index, etc. (Table 1).

\section{Relative relief}

Relative relief (RR), which is defined as the difference in height between the highest point and the lowest point on the grid of a square kilometer, can be categorized into six classes: extremely low $(R R=0-15$ $\mathrm{m})$, moderately low $(\mathrm{RR}=15-30 \mathrm{~m})$, low $(\mathrm{RR}=30-60$ $\mathrm{m})$, moderate $(\mathrm{RR}=60-120 \mathrm{~m}$ ), moderately high ( $R R$ $=120-240 \mathrm{~m})$ and high $(\mathrm{RR}>240 \mathrm{~m})$. The CRB possesses moderately low to moderately high relative relief (Fig. 10). The southern regions show moderately low RR, while the catchment areas and rest of the part consisting sandstone and mudstone sequences show moderately high RR (120-240 m), except the portion of the Bijaure Khola sub-basin and the central part of the Chure Khola, where mostly friable sandstone and loose conglomerate exist show moderate RR (60-120 $\mathrm{m})$.

\section{Dissection index}

Dissection index (DI) is the ratio of relative relief to absolute relief. Based on DI, the basin can be categorized into six categories: very low ( $\mathrm{DI}=0.0-0.1$ ), moderately low $(\mathrm{DI}=0.1-0.2)$, moderate $(\mathrm{DI}=$ $0.2-0.3)$, high $(\mathrm{DI}=0.3-0.4)$, and very high $(\mathrm{DI}>4)$. Majority of the portion of the CRB exhibits moderate to high DI. The area having moderate relief shows low DI (Fig. 11).

\section{Hypsometric analysis}

The hypsometric curve (Fig. 12 ) indicates inverse relationship between the elevation and the cumulative $\%$ area. The area having elevation between 300 and $500 \mathrm{~m}$ occupies the most of the basin area. The area of the elevation $>800 \mathrm{~m}$ is quite negligible.

\section{Average slope}

By counting the number of contour lines lying on each grid of square kilometer from the topographic sheets, average slope of the basin is calculated (Table 1). According the average slope in the basin can be classified into five categories (Singh, 1998): level slope $\left(\mathrm{S}=0-2^{\circ}\right)$, gentle slope $\left(\mathrm{S}=2-5^{\circ}\right)$, moderate slope $(\mathrm{S}$ $\left.=5-15^{\circ}\right)$, steep slope $\left(\mathrm{S}=15-30^{\circ}\right)$, and very steep slope $\left(\mathrm{S}>30^{\circ}\right)$. The CRB constitutes mainly three categories of slope, i.e., gentle, moderate and steep slopes (Fig. 13).

\section{Profile}

With progressive reworking by flow in river, the channel tends to alter its shape in both cross-section and its gradient. The Chure River is roughly 


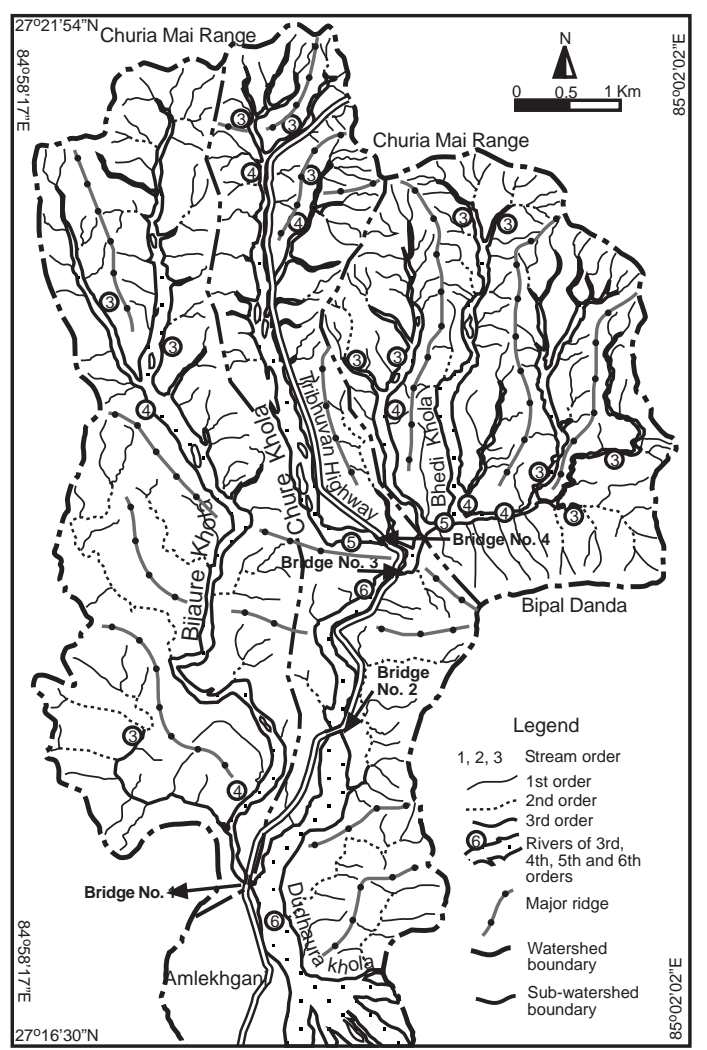

Fig. 8 Drainage order map of the Chure River Basin

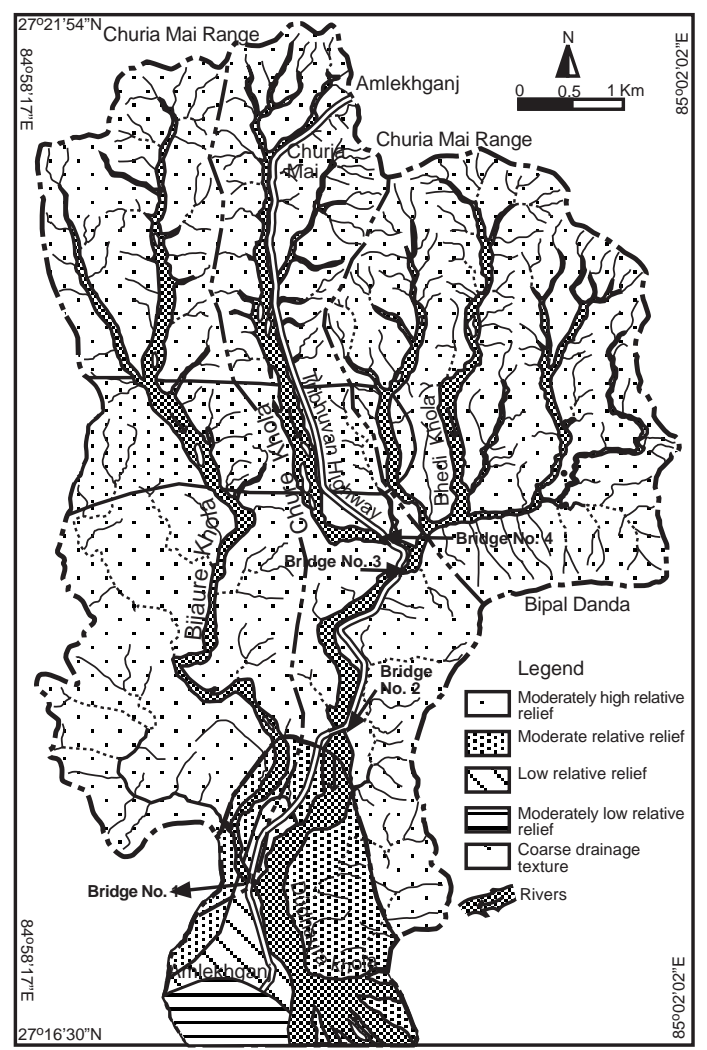

Fig. 10 Isopleth map showing relative relief of the Chure River Basin

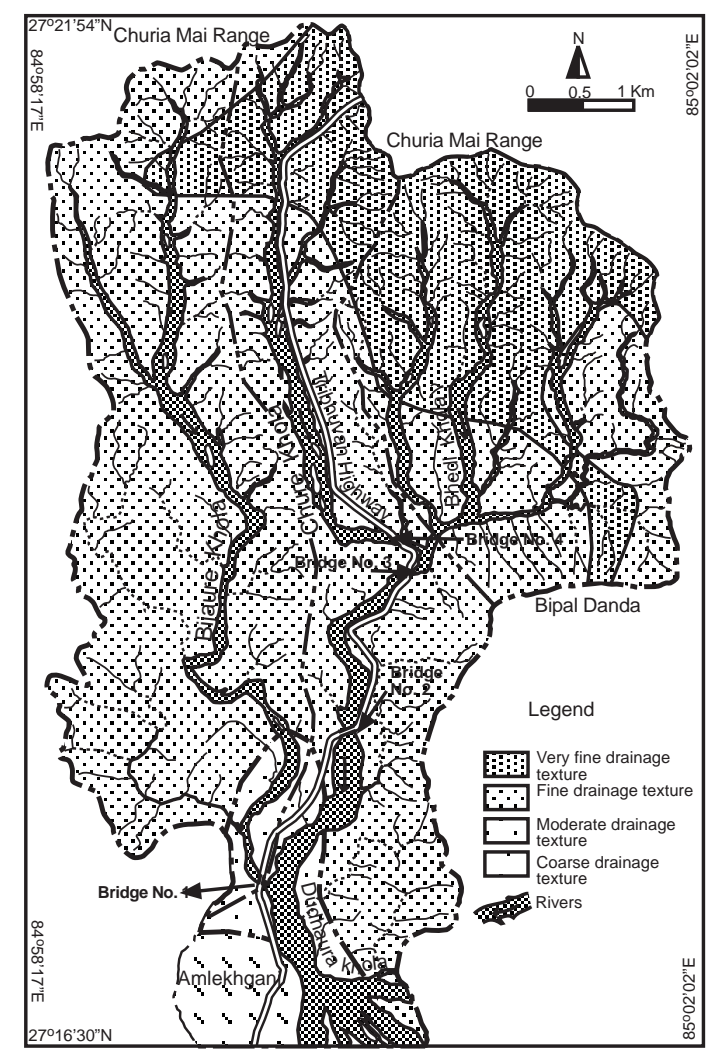

Fig. 9 Isopleth map showing drainage texture of the Chure River Basin

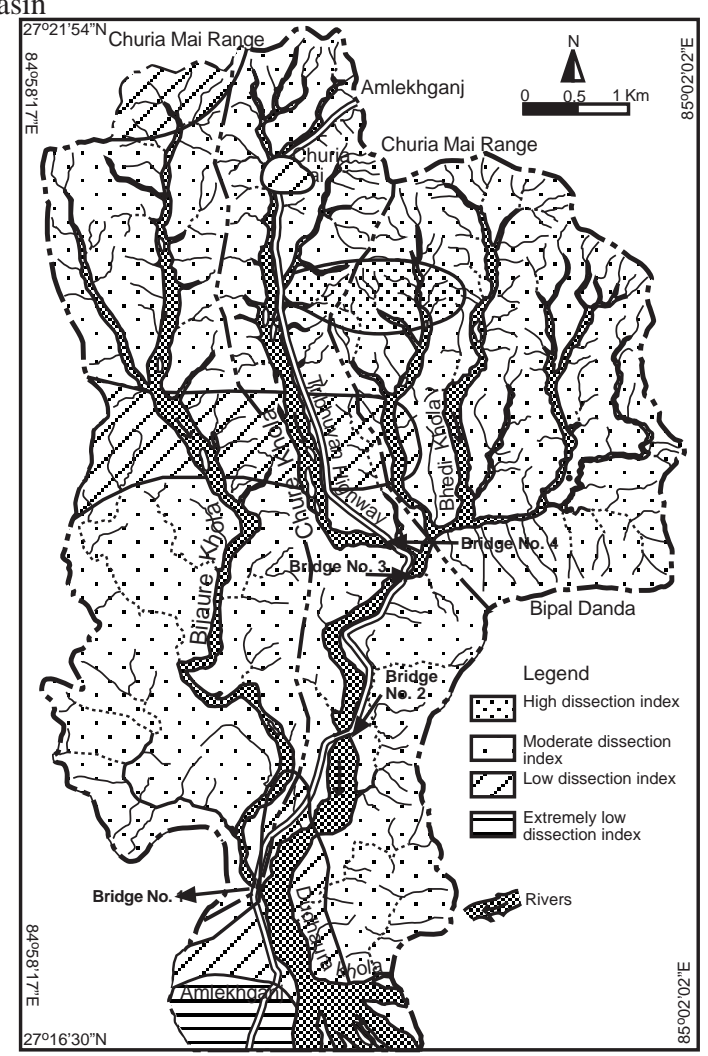

Fig. 11 Isopleth map showing dissection index of the Chure River Basin 


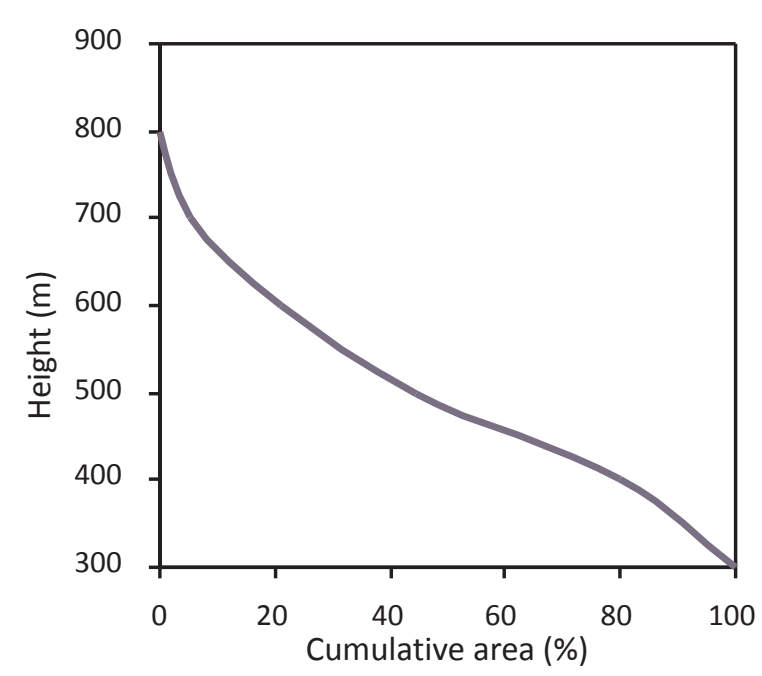

Fig. 12 Hypsometric curve of the Chure River Basin

perpendicular to the strike of the inclined strata. Within the CRB, landforms are mostly erosional type because streams are in erosional phase, cutting down the rock outcrop and leaving terraces at higher level. The longitudinal profile of the Chure River reflects its gradient throughout its length (Fig. 14). There are two knick points, one near the head and another near the downstream end. The steep slopes in the head water due to upliftment of the Churia Mai Range and subsequent formation of the Chure River and other tributaries. The knick point near the end of the profile is presumably due to the effect of the MFT. Therefore the stream is still immature and has tendency to erode its channel to accommodate it to the dynamic equilibrium.

\section{DISCUSSIONS AND CONCLUSIONS}

The Chure River Basin carries varied lithological identities across the north-south elongation of the basin, for instance gravelly terrain in the northern part to the very thick coarse-grained sandy in the middle portion extending southward to medium- to coarsegrained sandy and muddy sequences of the Siwaliks, and the Alluvial Fan gravels. Sub-dendritic to subparallel drainage patterns are more commonly formed on the low-angle dipping and loosely consolidated deposits of the Churia Mai Formation and the Churia Khola Formation. The sub-dendritic to rectangular patterns are developed on high angle dipping and folded strata of the Amlekhganj Formation and the
Rapti Formation, which comprise relatively more consolidated and stiff lithology. Most of the area of the CRB exhibits fine to very fine drainage texture (low values of DT), due to the presence of loosely consolidated and soft rocks. Even where rocks are stiff, the presence of discontinuity has perhaps influenced the DT. Very fine to fine drainage texture coupled with elongate nature of the basin (as indicated by low value of form factor) is vulnerable to flooding during high rainfall.

Relative relief, average slope and dissection index are found to be high in the Ridge forming Amlekhganj Formation and the lower part of the Churia Mai Formation (which is stiff due to calcareous cements), while these indices are low in other areas. High dissection, high slopes and relief show active and immature nature of the CRB, which should have been entrenched by the river system against uplift due to tectonics, and also these parameters would reflect susceptibility of the other phenomena such as landsliding, erosion, and flooding in the CRB.

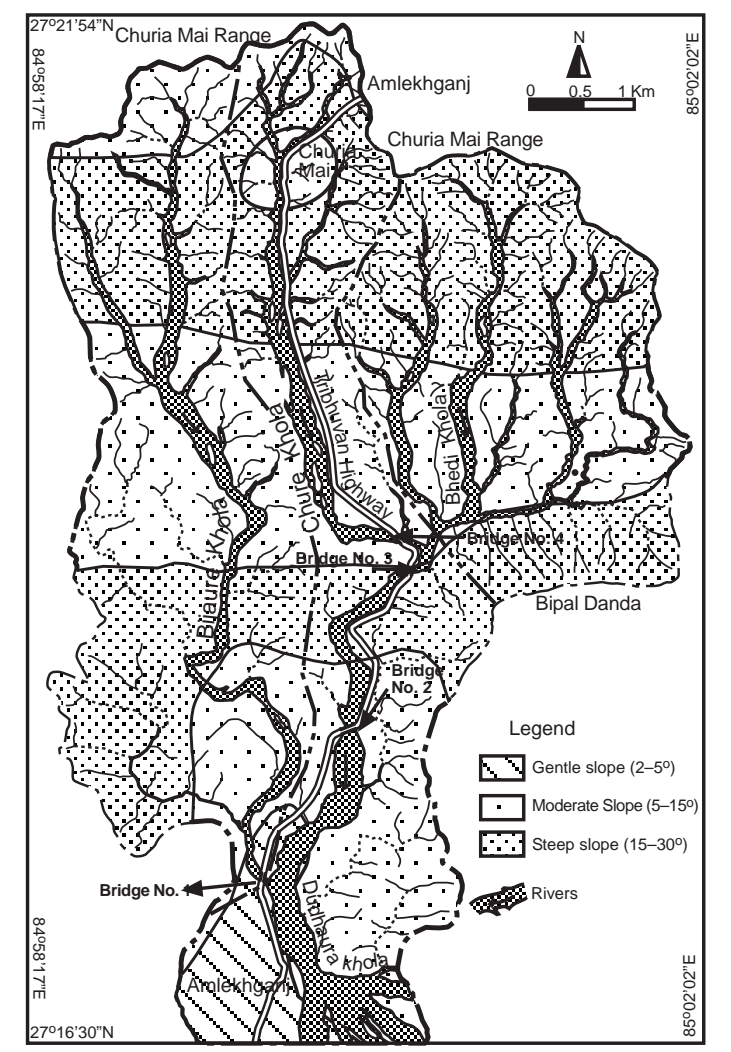

Fig. 13 Isopleth map showing distribution of slope of the Chure River Basin 


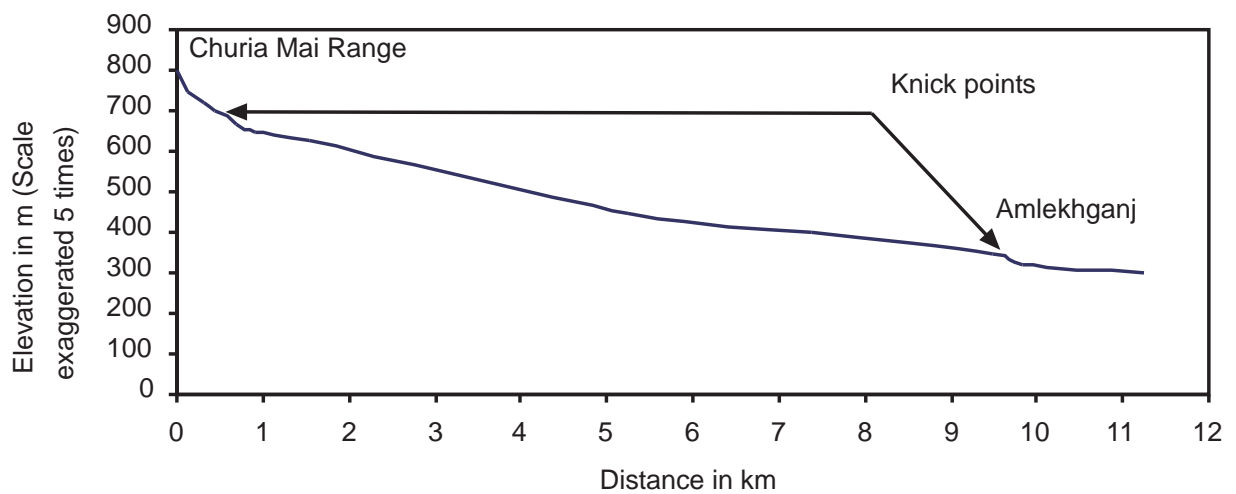

Fig. 14 A longitudinal profile of the Chure River

Presence of knick points along the river profile reflects affinity of the river to incision. The sinuosity, radius of curvature, and bifurcation ratio, all indicate immaturity of the basin. The hypsometric analysis indicates inverse relationship between the elevation and the cumulative \%area, showing active erosional condition of the basin.

\section{ACKNOWLEDGEMENTS}

Authors are thankful to the Central Department of Geology for providing field equipments, and to $\mathrm{R}$. Dhakal for assistance during fieldwork.

\section{REFERENCES}

Gautam, P., Rösler, W., 1999. Depositional chronology and fabric of Siwalik group sediments in Central Nepal from magnetostratigraphy and magnetic anisotropy. Journal of Asian Earth Sciences 17, pp.659-682. http://dx.doi.org/10.1016/S13679120(99)00021-8

Ghimire, S.K., Higaki, D., and Bhattarai, T.P., 2006. Gully erosion in the Siwalik Hills, Nepal: estimation of sediment production from active ephemeral gullies. Earth Surface Processes and Landform, v. 31., pp. 155-165. http://dx.doi.org/10.1002/esp.1320

Horton, R.E., 1932. Drainage basin characteristics. Trans. Am. Geophysc. Union 13:350-361. http://dx.doi.org/10.1029/TR013i001p00350

Horton, R.E., 1945. Erosional development of streams and the streams and their drainage basins: Hydrological approach to quantitative geomorphology. Bulletin of the Geological Society of America, Vol. 56, pp. 275-370. http://dx.doi.org/10.1130/00167606(1945)56[275:EDOSAT]2.0.CO;2

Leopold, L.B. and M.G. Wolman, 1957. River channel pattern-braided, meandering and straight, USGS
Professional Paper 282B.

Leopold, L.B., Wolman, M.G. and Miller, J.P., 1964. Fluvial processes in Geomorphology, W.H. Freeman, San fransisco.

Sah, R.B., Ulak, P.D., Gajurel, A.P., Rimal, L.N., 1994. Lithostratigraphy of Siwalik Sediments of Amlekhganu-Hetauda area, Sub-Himalaya of Nepal. Himalayan Geology 15, 37-48.

Schumm, S.A., 1956. Evolution of drainage system and slope in badlands of Perth Amboy, New Jersy. Bull. Geo. Soc.Am 67: 597-46.

h t t p : / / d . doi.org/10.1130/00167606(1956)67[597:EODSAS]2.0.CO;2

Singh, S., 1981. Estimation of drainage density, National Geographer, Vol. 16. No. 2, pp. 81-89.

Strahler, A.N., 1957. Quantitative analysis of watershed geometry. Trans-American Geophysical Union, v. 38, pp. 913-920.

http://dx.doi.org/10.1029/TR038i006p00913

Strahler, A.N., 1964. Quantitative geomorphology of drainage basins and channel networks, In: VT Chow (ed), Handbook of Applied Hydrology. McGrew Hill Book Company, New York, Section, pp. 4-11.

Strahler, A.N., 1969. Physical Geography. 3rd edition, John Willey and Sons, Inc. New York.

Tamrakar, N.K., Khakurel, D., 2001. In-situ Schmidt hammer hardness of sandstones Amlekhganj-Suparitar area, Siwalik Hills, Central Nepal. Bulletin of Department of Geology, vol. 8. Tribhuvan University, Kathmandu, pp. 35-48.

Tamrakar, N.K., Yokota, S., Shrestha, S.D., 2003. Petrography of the Siwalik sandstones, Amlekhganj-Suparitar area, central Nepal Himalaya. Journal of Nepal Geological Society 28, pp. 41-56.

Tamrakar, N.K., Yokota, S., Shrestha, S.D., 2002. Physical and geomechanical properties of the Siwalik sandstones, Amlekhganj-Suparitar area, central Nepal Himalaya. Jour. Nepal Geol. Soc., v. 26, pp. 59-71. 